\title{
PELATIHAN DAN PERTUNJUKAN MUSIK BAGI ANAK PANTI ASUHAN YAYASAN KASIH MANDIRI BERSINAR
}

\author{
Dani Nur Saputra ${ }^{1}$, Clemy Ikasari ${ }^{2}$ \\ Fakultas Bahasa dan Seni, Universitas Negeri Jakarta
}

\begin{abstract}
Abstrak
Yayasan Kasih Mandiri Bersinar mempunya visi yaitu kepedulian yang mendalam terhadap pergulatan hidup anak-anak dan remaja jalanan yang tersisih dan mengembalikan hak-hak mereka yang hilang. Sejalan dengan visi yayasan maka pengabdian kepada masyarakat dilakukan atas dasar kepedulian terhadap anak-anak yang tinggal di yayasan. Tujuan dari kegiatan yang dilakukan yaitu memberikan layanan berupa pelatihan keterampilan bermain musik dan bernyanyi. Melalui musik, anak di ajarkan untuk mendapat posisi dan peran yang layak dihargai dan saling menghargai, anak dilatih untuk berkolaborasi dan bekerja sama dalam kelompok, anak di latih untuk memiliki rasa percaya diri dan menghargai orang lain, anak dilatih untuk membuka diri dan mengungkapkan perasaan melalui musik. Tujuan yang terakhir sebagai hasil dari pengabdian ini yaitu anak-anak memiliki bekal keterampilan bermusik dan bernyanyi yang diharapkan berguna bagi masa depan mereka. Metode Pelaksanaan yang dilakukan dalam program pengabdian kepada masyarakat dilakukan melalui program pelatihan bernyanyi dan bermain musik di Yayasan Kasih Mandiri Bersinar yang dilaksanakan selama empat bulan. Tim pengabdian terlibat langsung dalam interaksi dengan anak-anak baik dalam melatih, pemberian arahan, pertunjukan, bimbingan mental.
\end{abstract}

Kata kunci: Pelatihan, Pertunjukan Musik, Anak-anak, Panti asuhan

\begin{abstract}
The Kasih Mandiri Bersinar Foundation has a vision that is a deep concern for the struggles of the lives of children and street teenagers who are marginalized and to restore their lost rights. In line with the foundation's vision, community service is carried out on the basis of caring for the children who live in the foundation. The purpose of the activities carried out is to provide services in the form of training in playing music and singing skills. Through music, children are taught to get positions and roles that deserve respect and mutual respect, children are trained to collaborate and work together in groups, children are trained to have self-confidence and respect for others, children are trained to open up and express feelings through music. The final goal as a result of this dedication is that children have musical and singing skills that are expected to be useful for their future. Methods of implementation in the community service program are carried out through a singing and playing music training program at the Kasih Mandiri Bersinar Foundation which is held for four months. The service team is directly involved in interactions with children both in training, giving directions, performing, mental guidance.
\end{abstract}

Keywords: Training, Music performance, Childrens, orphanage

Correspondence author: Dani Nur Saputra, daninursaputra6@gmail.com, Jakarta, Indonesia 


\section{PENDAHULUAN}

Pendidikan sebenarnya menjadi andil yang cukup penting untuk menunjang kesejahteraan masyarakat Indonesia, akan tetapi kemiskinan menyebabkan tingkat pendidikan di Indonesia menjadi rendah. Di sektor sosial, banyak masalah yang perlu penanganan segera. Salah satu masalah itu adalah perkembangan jumlah anak jalanan yang belakangan ini makin mencemaskan. Anak jalanan termasuk dalam golongan orangorang miskin yang tidak bisa memenuhi kebutuhan hidupnya sehari-hari sehingga mereka harus terjun ke jalanan untuk mengamen dan mengemis. Pendidikan yang sedianya merupakan hal yang penting sebagai bekal agar seseorang dapat mencari mata pencaharian melalui bekerja bagi pemberdayaannya, jika tidak terlaksana dengan baik maka akan mengakibatkan timbulnya pengangguran yang berdampak pada kemiskinan dan ketidak berdayaannya. Berawal dari fenomena tersebut maka hadirlah Panti Asuhan Yayasan Kasih Mandiri Bersinar (YKMB).

Panti Asuhan Yayasan Kasih Mandiri Bersinar (YKMB) merupakan salah satu panti asuhan yang berada di Jakarta. Yayasan ini terletak di Jl.Bambu kuning No.27, RT 08 RW 01, Jati Padang, Pasar Minggu, Jakarta Selatan. Panti Asuhan ini dihuni oleh bayi, anak-anak, remaja, sampai usia dewasa dengan segala latar belakang yang berbeda. Panti Asuhan YKMB ini diurus oleh para biarawati yang sekaligus menjadi orang tua bagi anak-anak di Panti Asuhan.

Atas dasar kepedulian mendalam terhadap keberadaan dan pergulatan hidup anak dan remaja jalanan miskin dan terlantar dengan mendidik, melindungi, menyehatkan dan mengembalikan hak-haknya yang telah hilang menjadi sebuah bentuk visi berdirinya panti asuhan ini, sehingga terciptalah perkembangan dan kemandirian pribadi yang bermartabat dan menjunjung nilai-nilai iman moral dan sosial. Bagi anak-anak, Panti Asuhan YKMB selalu menjadi kekuatan bagi para pengurus untuk dapat melanjutkan misi pelayanan bagi anak-anak untuk dapat menggapai cita-cita dan kehidupan yang lebih baik.

Sampai saat ini jumlah anak binaan Panti Asuhan YKMB terdiri atas Balita: 11 anak, SD: 23 anak, SLTP: 24 anak, SMU/SMK: 24 anak, Mahasiswa: 11 anak, Remaja/Bina Lanjut: 6 anak. Total 99 anak. Yayasan Kasih Mandiri Bersinar di dirikan oleh Sr. M. Alexa Yonsion, OP. Latar belakang beliau mendirikan tempat tersebut karena panggilan hati ketika ia masih kuliah dan menjalani salah satu program universitas untuk terjun dan tinggal bersama anak-anak jalanan di Jakarta. Ketika beliau menyelesaikan studinya, beliau terpanggil untuk kembali terjun ke dunia anak jalanan dan berkeinginan membantu mereka. Sehingga ia mendirikan tempat agar para anak jalanan tidak terlantar.

Latar belakang lainnya yang memprakasrsai berdirinya yayasan ini adalah keprihatinan yang mendalam terhadap kehidupan anak-anak dan remaja jalanan Jakarta dan sekitarnya yang tidak punya siapa-siapa. Mereka tersisih dari kehidupan yang normal sorang anak dan remaja. Yayasan Kasih Mandiri Bersinar mempunya visi yaitu kepedulian yang mendalam terhadap pergulatan hidup anak-anak dan remaja jalanan yang tersisih dan mengembalikan hak-hak mereka yang hilang menjadi sebuah bentuk penghadiran kasih Allah yang menyelamatkan, sehingga tercipta kemandirian yang bermartabat dan menjunjung tinggi nilai iman, moral, dan sosial.

Yayasan ini juga memiliki misi antara lain mengusahakan dan menyalurkan dan pendidikan yang dapat menyokong pendidikan formal anak lewat pemberian beasiswa kepada anak-anak sekolah dalam wilayah pendampingan kami. Membangun sebuah keluarga alternatif dalam kehidupan yang penuh kasih. Pendampingan berkala bagi anakanak dan remaja seperti di stasiun, terminal dan daerah kumuh. 
Yayasan yang berdiri sejak 1995 tersebut menyimpan berbagai cerita dan saksi hidup para anak-anak penghuni yayasan. Dari cerita yang membuat tertawa sampai cerita yang membuat sedih dan terharu. Cerita sedih banyak muncul dari kalangan anak-anak yang di tinggal kedua orang tuanya dan di telantarkan dijalanan. Bahkan tidak sedikit anak yang mencoba untuk mengakhiri hidup mereka. Oleh karena itu, pendiri yayasan ini, Suster Alexa berusaha untuk menyelamatkan anak-anak yang kehilangan arah hidup mereka, bahkan kehilangan jiwa mereka walaupun mereka masih hidup.

Salah satu misi yang di lakukan oleh mitra untuk mencapai visinya adalah menyelenggarakan kursus keterampilan untuk masa depan mereka yang hendak mandiri. Berdasarkan misi tersebut maka mitra memiliki pemasalahan yaitu tidak adanya pengajar yang bersedia sukarela mengajarkan keterampilan kepada anak-anak. Berdasarkan latar belakang permasalahan yang dialami mitra, maka tim pengabdian kepada masyarakat hendak melaksanakan program kegiatan pengabdian untuk membantu pihak yayasan dalam membekali keterampilan anak-anak di yayasan melalui pelatihan musik dan bernyanyi. Pelatihan yang diadakan merupakan salah satu cara menanamkan sikap kepedulian terhadap sesama manusia. Pelatihan tersebut dapat memberikan bekal keterampilan bagi anak-anak untuk memiliki pengetahuan dan keterampilan di bidang seni musik. Penanaman mental dan pendidikan karakter juga turut di selipkan selama proses pelatihan agar anak-anak memiliki motivasi dan semangat untuk mengejar citacita mereka. Anak-anak tidak lagi merasa sendiri, minder, tidak memiliki orang tua, tidak tahu harus kemana dan menjadi apa. Oleh sebab itu tim dalam rangka menjalankan program tridharma perguruan tinggi ini bersinergi untuk membentuk sikap mental dan keterampilan anak-anak yang tinggal dan di asuh di panti asuhan Yayasan Kasih Mandiri Bersinar.

\section{METODE PELAKSANAAN}

Metode Pelakasanaan yang dilakukan dalam program pengabdian kepada masyarakat dilakukan melalui program pelatihan seni musik yang telah disepakati melalui ikatan kerjasama antar dua instansi. Kegiatan tersebut dilakukan dalam rentan waktu yang telah ditetapkan bersama antara pihak Tim P2M Program studi pendidikan mudik, UNJ dengan Yayasan Kasih Mandiri Bersinar. Pelaksanaan pengabdian kepada masyarakat ini, pihak yayasan menyediakan tempat untuk di jalankannya program. Pihak tim pengabdian kepada masyarakat akan melakukan sebuah pelatihan musik di Yayasan Kasih Mandiri Bersinar.

Pelatihan akan dilakukan selama empat bulan. Pelatihan yang akan dilakukan melibatkan anak-anak di yayasan, mereka akan dikenalkan dan dilatih dalam bermain musik dan bernanyi. Tim P2M akan terjun langsung dan berinteraksi dengan anak-anak baik dalam pengajaran, pelatihan, serta membangun motivasi dan kepercayaan diri anak untuk terlibat dalam sebuah kelompok melalui permainan musik dan bernyanyi. Tim juga akan menghadirkan narasumber yang berkecimpung dibidang psikologi perkembangan anak di setiap sesi pelatihan sebagai sarana penunjang keberhasilan dalam proses pengabdian kepada masyarakat yang dilakukan di Yayasan Kasih Mandiri Bersinar. 


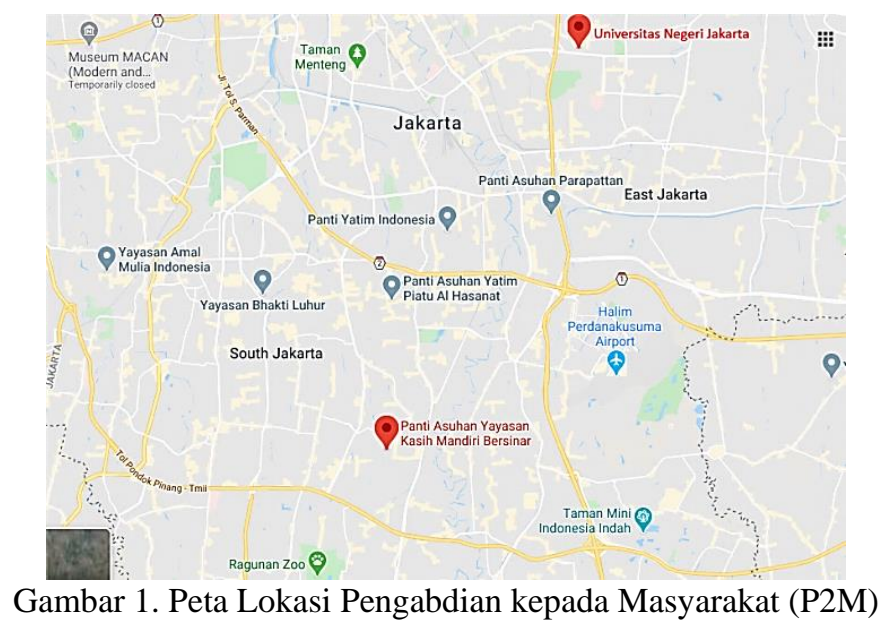

Pengabdian ini dilaksanakan di Jl. Bambu Kuning No.27, RW.1, Jati Padang, Kec. Ps. Minggu, Kota Jakarta Selatan, Daerah Khusus Ibukota Jakarta 12540. Sasaran dari penelitian ini adalah anak-anak Panti Asuhan Yayasan Kasih Mandiri Bersinar. Terdapat beberapa aspek tujuan dalam pengabdian kepada masyarakat di Yayasan Kasih Mandiri Bersinar yang dilakukan oleh tim P2M antara lain sebagai berikut :

1. Sebagai sarana pengabdian untuk membantu pemerintah khususnya Dinas Sosial daerah khusus ibukota Jakarta dalam memberikan layanan pendidikan dan pelatihan di bidang seni budaya dan keterampilan musik di lembaga panti asuhan anak. Kesadaran dan kepedulian sejumlah orang saat ini sudah pada tingkat menghawatirkan karena perubahan zaman dan tuntutan ekonomi menyebabkan orang fokus pada dirinya sendiri tanpa melihat dan mempedulikan sesamanya, sehingga dengan adanya program ini diharapkan dapat memunculkan rasa kepedulian antar sesama.

2. Mengikutsertakan masyarakat akademik dalam upaya mendukung, mengembangkan, dan menjunjung nilai-nalai kemanusiaan, nilai sosial, dan nilai seni.

3. Pengembangan program kerja sama antara civitas UNJ dengan Yayasan Kasih Mandiri Bersinar terkait di bidang pendidikan dan pelatihan.

4. Meningkatkan sinergitas dan pengembangan pelaksanaan program-program di bidang pendidikan dan pelatihan serta untuk meningkatkan kualitas pelayanan publik dan pengabdian kepada masyarakat.

5. Meningkatkan minat dan motivasi bagi anak-anak panti asuhan Yayasan Kasih Mandiri Bersinar.

\section{HASIL DAN PEMBAHASAN}

Pelatihan musik dan bernyanyi yang dilakukan merupakan salah satu kegiatan pengabdian masyarakat yang bertujuan untuk meningkatkan sinergitas dan mengembangkan pelaksanaan program-program di bidang pendidikan, kebudayaan, sosial, serta untuk meningkatkan kualitas pelayanan publik, pengabdian kepada masyarakat, dan pelestarian budaya. Selain itu, program ini dilakukan atas dasar kepedulian antar sesama dan memberikan motivasi serta memberikan pendidikan karakter bagi anak-anak di Panti Asuhan Yayasan Kasih Mandiri Bersinar.

Kegiatan ini melibatkan anak-anak Panti Asuhan Yayasan Kasih Mandiri Bersinar dan para pelatih yang terdiri atas dosen, narasumber dan mahasiswa program studi pendidikan musik, UNJ. Dalam pelaksanaan kegiatan pengabdian kepada masyarakat ini 
tidak akan lepas dari keterkaitan lembaga, instansi, serta individu lainnya yang terlibat yaitu Universitas Negeri Jakarta dan Panti Asuhan Yayasan Kasih Mandiri Bersinar.

Proses pelaksanaan pelatihan yang dilakukan ini cukup terhambat karena adanya pandemic virus covid 19. Akan tetapi kegiatan sempat berjalan sebanyak 3 kali pertemuan sebelum Jakarta dilakukan Pembatasan Sosial Berskala Besar (PSBB) kemudian dilanjutkan 3 kali pertemuan pada bulan Agustus dan September. Pertemuan Pertama dilakukan pada tanggal 7 Maret 2020. Adapun kegiatan yang dilakukan pada pertemuan pertama adalah kunjungan awal tim P2M sekaligus melakukan koordinasi dengan mitra. Pimpinan yayasan mengemukakan sejarah latar belakang berdirinya panti asuhan Yayasan Kasih Mandiri Bersinar. Selain itu, pimpinan yayasan juga mengatakan bahwa mereka sangat senang apabila ada seseorang yang terpanggil untuk berbagi pengalaman maupun ilmu untuk diberikan kepada anak-anak di panti asuhan tersebut. Setelah koordinasi dilakukan maka pihak yayasan menyambut baik kedatangan tim P2M dari UNJ untuk memberikan bekal keterampilan bernyanyi dan bermain musik bagi anak-anak di panti asuhan tersebut.

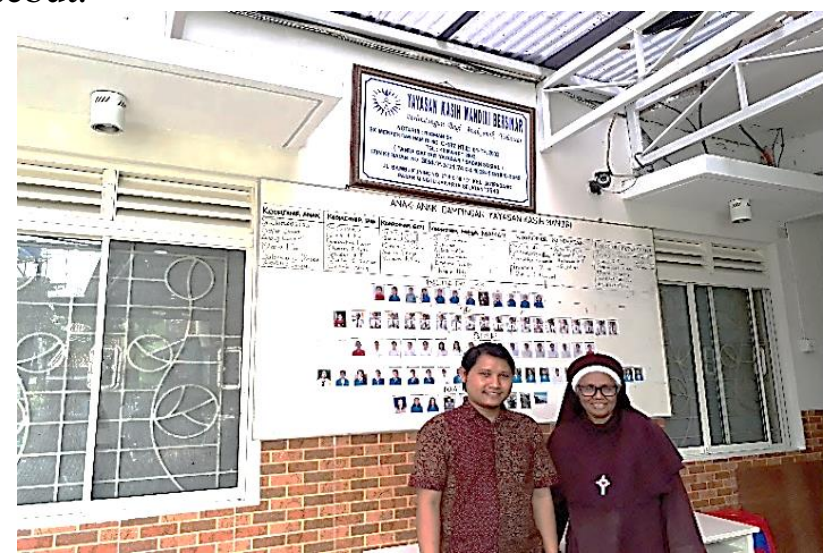

Gambar 2. Foto Bersama ketua Yayasan Kasih Mandiri Bersinar

Kegiatan selanjutnya, Tim P2M melakukan observasi di Yayasan Kasih Mandiri Bersinar. Berdasarkan observasi yang dilakukan, tim hanya melihat 1 buah gitar yang ada di panti tersebut sehingga peneliti memutuskan untuk memberikan keterampilan anakanak dalam hal bernyanyi. Tidak menutup kemungkinan tim akan mengajarkan alat musik gitar kepada anak-anak panti asuhan Yayasan Kasih Mandiri Bersinar. Saat observasi dilakukan, Tim juga sempat bertegur sapa dengan anak-anak panti asuhan dan para pengasuh. Kedatangan Tim di yayasan tersebut disambut baik oleh anak-anak dan para pengasuh serta pimpinan panti asuhan Yayasan Kasih Mandiri Bersinar.

Pada pertemuan kedua dilakukan pada tanggal 14 Maret 2020. Kegiatan pelatihan pada pertemuan kedua dilakukan pada pukul 09.00 wib sampai dengan pukul 13.00 wib. Kegiatan diawali dengan koordinasi dan persiapan yang dilakukan antara tim dan pihak yayasan. Kegiatan dilanjutkan perkenalan dengan anak-anak panti asuhan Yayasan Kasih Mandiri Bersinar. Kegiatan dilanjutkan dengan latihan bernyanyi bersama. Anak-anak yang dilatih pada pertemuan ini merupakan anak-anak usia SMP dan yang sebagian besar berlatar belakang dari anak jalanan. Walaupun anak jalanan, mereka dapat mengikuti instruksi arahan dengan baik dari tim pengajar. Materi lagu yang diberikan pada latihan pertama yaitu Mujizat itu nyata. Kegiatan pelatihan diawali oleh pengajar dengan mengajarkan lirik lagu kemudian di ikuti olah anak-anak yayasan untuk dinyanyikan bersama. 


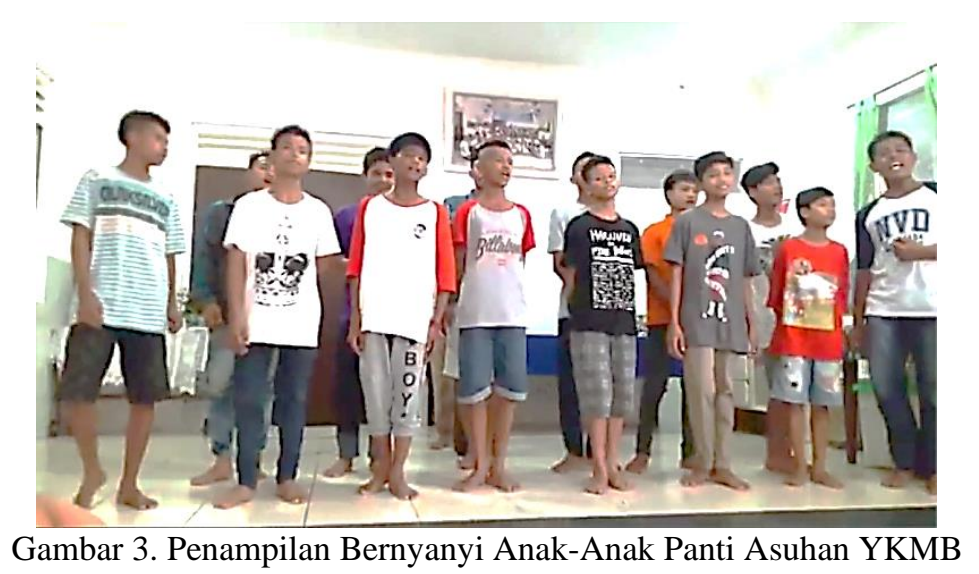

Pada pertemuan kedua, dilakukan penampilan bernyanyi yang dilakukan oleh sebagian anak-anak panti asuhan pada tingkatan SMP. Walaupun anak-anak belum menguasai lagu yang di ajarkan namun semangat untuk belajar yang dimiliki sangat tinggi sehingga Tim bersemanga untuk membekali keterampilan bagi mereka.

Pada akhir pertemuan kedua tim bersama ketua yayasan melakukan evaluasi terhadap kegiatan yang telah dilakukan. Kegiatan latihan bernyanyi bersama yang dilakukan mendapatkan respon cukup baik dari anak-anak maupun para pengasuh di panti asuhan yayasan tersebut.

Pada pertemuan ketiga dilakukan pada tanggal 21 Maret 2020. Pelatihan dilakukan pada pukul 09.00 wib sampai dengan pukul 12.00 wib. Kegiatan pelatihan pada pertemuan ketiga diberikan untuk anak yang berusia di bawah 10 tahun. Materi yang diajarkan adalah gerak dan lagu. Lagu yang dipelajari pada pertemuan kedua adalah Hatihati gunakan tanganmu. Kegiatan pelatihan dimulai dengan pertunjukan anak-anak panti asuhan Yayasan Kasih Mandiri Bersinar untuk menampilkan lagu yang sudah mereka kuasai. Kemudian tim memberikan pengajaran materi lagu beserta gerak untuk mereka tirukan. Adapun hasil penampilan yang bawakan oleh anak-anak cukup baik dan membuat mereka terlihat bahagia tertawa bersama.

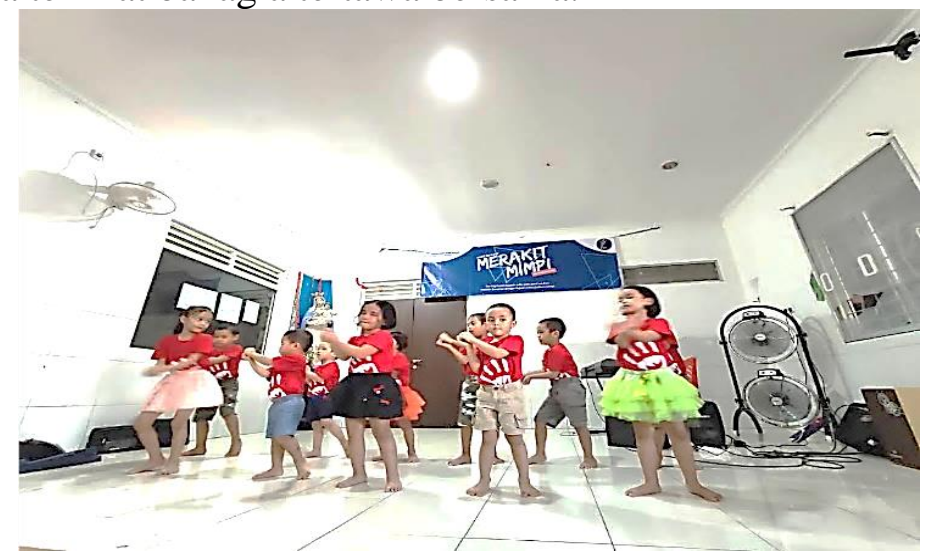

Gambar 4. Penampilan Gerak dan Lagu Anak-Anak Panti Asuhan YKMB

Terdapat beberapa kendala yang dialami oleh tim pengabdian antara lain kemampuan konsentrasi anak-anak belum optimal. Beberapa anak belum memiliki kemampuan bernyanyi sehingga terdapat beberapa anak yang masih kurang tepat dalam menyanyikan nada. Kendala tersebut tidak menjadi hambatan bagi tim karena pelatihan yang dilakukan berorientasi pada pemberian kemampuan dan keterampilan untuk anakanak dan memberikan penghiburan bagi mereka. 
Proses pelatihan bernyanyi diakhiri dengan penampilan dari anak-anak untuk menunjukan kepada para pengasuh yayasan tentang apa yang telah mereka pelajari. Para pengasuh sangat senang dengan hasil latihan yang anak-anak pelajari. Anak-anak yang dilatih juga turut senang dengan kehadiran tim sebagai pengajar yang memberikan kemampuan bernyanyi bagi mereka.

Pelatihan yang dilakukan pada pertemuan ketiga merupakan pertemuan terakhir karena adanya wabah virus pandemic covid 19. Kondisi tersebut membuat Yayasan Kasih Mandiri Bersinar harus menghentikan segala aktivitas pembelajaran khususnya yang melibatkan pihak dari luar yayasan. Tim P2M terpaksa tidak dapat melanjutkan pelatihan sampai waktu yang tidak dapat ditentukan. Awalnya, tim berencana melakukan pelatihan secara daring online. Namun hal tersebut tidak dapat dilakukan karena keterbatasan perangkat yang dimiliki oleh pihak yayasan. Sehingga pelatihan dalam program pengabdian kepada masyarakat harus dihentikan pada pertemuan ketiga. Hal ini dilakukan dengan mengikuti kebijakan pemerintah, fakultas dan universitas untuk menyesuaikan kegiatan dengan keadaan pandemic virus covid 19.

Setelah menjalani masa pembekuan selama beberapa bulan, Tim kembali melakukan pelatihan pada pertemuan keempat pada tanggal 29 Agustus 2020. Pelatihan dilakukan dan diawasi ketat oleh pihak panti asuhan. Pelatihan dilakukanh dengan mengikuti protocol kesehatan dalam pencegahan penularan virus covid 19. Pelatihanpun diberikan batasan waktu maksimal hanya 60 menit. Sehingga tim pengabdian berusaha untuk menggunakan waktu dengan seefektif mungkin.

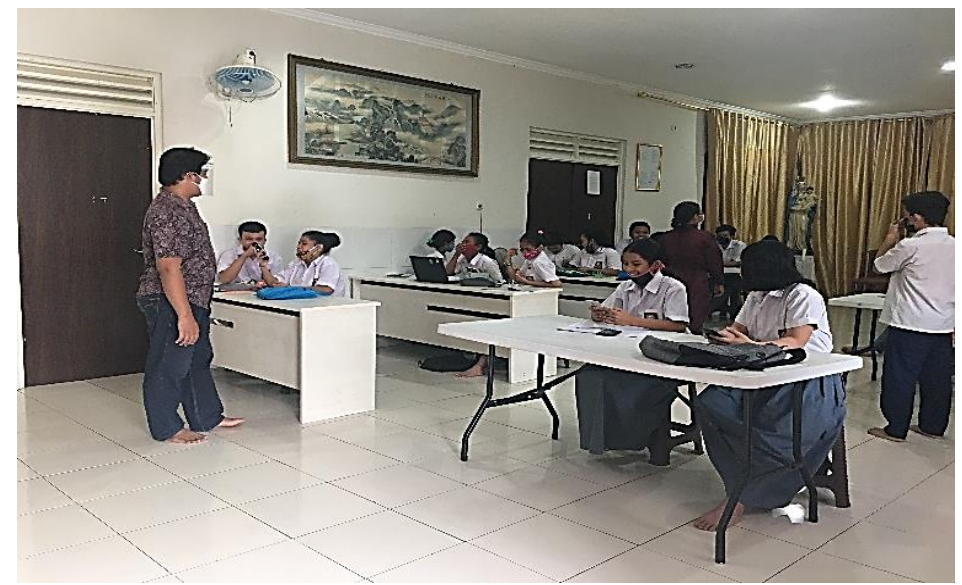

Gambar 5. Pelatihan Teknik Bernyanyi di Panti Asuhan Yayasan Kasih Mandiri Bersinar

Pelatihan kembali dilakukan dengan tetap memperhatikan protocol kesehatan. Pelatihan dilakukan disela-sela jam saat siswa sedang melaksanakan kelas online. Pada pertemuan keempat dilakukan setelah menjalani masa penutupan pihak yayasan selama beberapa bulan karena adanya virus covid 19. Pada pertemuan tersebut tim mengajarkan tentang materi apresiasi seni dan teknik bernyanyi. Kegiatan dilakukan dengan dengan menggunakan media youtube untuk mereka melihat pertunjukan musik kemudian memberikan penilaian terhadap pertunjukan yang mereka lihat. Kegiatan dilanjutkan dengan pengajaran teknik bernyanyi.

Kegiatan dilanjutkan pertemuan kelima pada tanggal 5 September 2020. Kegiatan dilakukan dengan pemberian materi pelatihan alat musik gitar dan bernyanyi. Selain itu, Anak-anak panti asuhan diajarkan tentang olah rasa dan mencari nada yang tepat antara bernyanyi dan menentukan akord yang dipakai pada permainan gitar pengiring. 


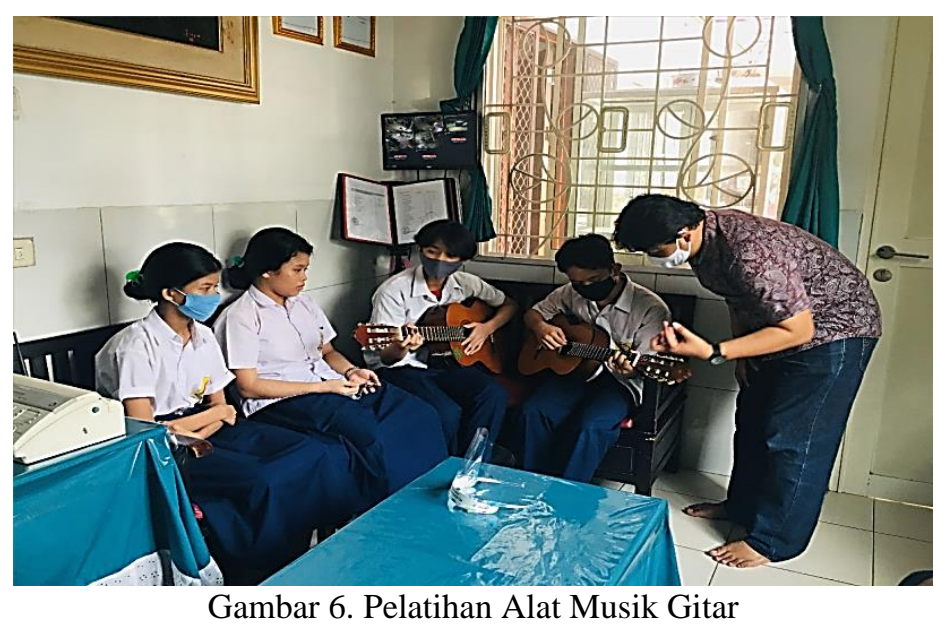

Pertemuan kelima dilakukan untuk mengajarkan keterampilan bermain musik gitar bagi anak-anak di panti asuhan yayasan kasih mandiri bersinar. Pelatihan dilakukan dengan tetap memperhatikan protocol kesehatan. Pelatihan dilakukan dengan menggunakan masker dan tidak berinteraksi secara kontak fisik antara tim pelatih dan anak-anak yayasan panti asuhan.

Kegiatan dilanjutkan pada pertemuan terakhir yaitu pertemuan keenam. Pertemuan keenam dilakukan pada tanggal 8 september 2020. Kegiatan dilakukan dengan pertunjukan musik oleh anak-anak di panti asuhan yayasan kasih mandiri bersinar dan di akhiri dengan sesi foto bersama.

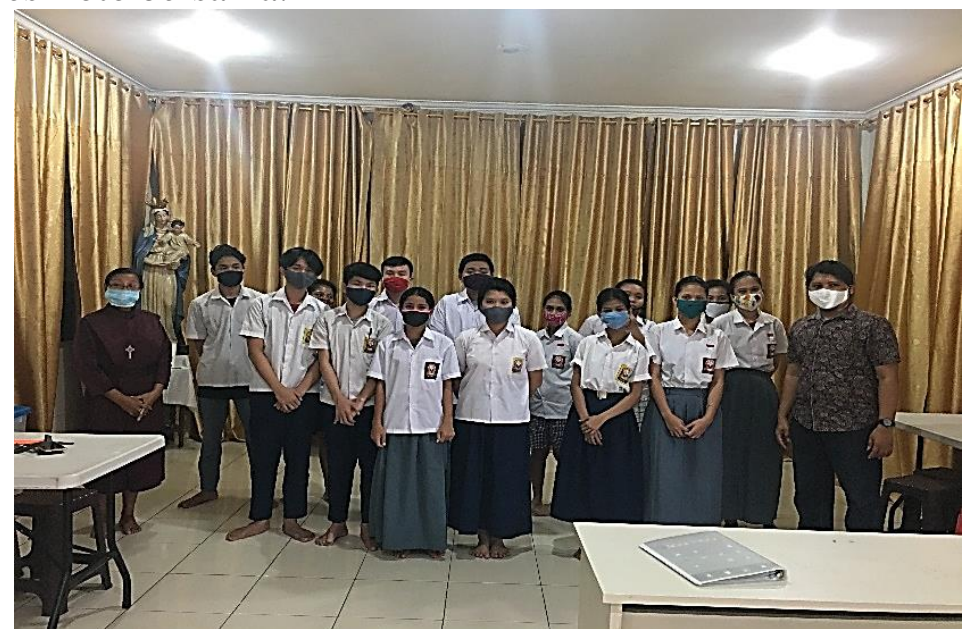

Gambar 7. Foto bersama Ketua Tim P2M Bersama Anak-Anak Panti Asuhan.

\section{SIMPULAN}

Kegiatan Pelatihan dan pertunjukan music yang dilakukan di panti asuhan yayasan kasih mandiri bersinar berjalan dengan baik walaupun sempat mengalami masa vakum selama beberapa bulan karena adanya pandemic virus covid 19. Pertunjukan musik dan bernyanyi yang dilakukan oleh anak-anak panti asuhan memunculkan antusias dan semangat belajar yang tinggi. Pada pertemuan awal, Tim mengalami kesulitan dalam mengajarkan bernyanyi karena beberapa anak tidak mengenal nada. Akan tetapi berkat usaha yang keras dari anak untuk belajar sampai pada akhirnya sebagian besar dari mereka sudah bisa bernyanyi dengan nada yang tepat. Dengan adanya pelatihan yang dilakukan oleh tim P2M membuahkan hasil yang signifikan dimana kondisi awal anakanak tidak menguasai teknik bernyanyi dan bermain musik. Program pelatihan musik dan 
bernyanyi yang dilakukan dapat menjawab persoalan yang terdapat pada latar belakang dilakukannya pengabdian kepada masyarakat di panti asuhan yayasan kasih mandiri bersinar. Kegiatan yang dilakukan sangat terbatas karena adanya pandemic virus covid 19. Sehingga program pelatihan music tetap harus diadakan kembali sebagai program lanjutan untuk mengembangkan potensi anak-anak di panti asuhan.

\section{DAFTAR PUSTAKA}

Baihaqi, MIF. 2008. Psikologi Perkembangan. Bandung: PT. Remaja Rosdakarya

Februariyanti, Herny, dkk. 2017. Peningkatan Keterampilan Anak Panti Asuhan Melalui Pelatihan Multimedia Kreatif. Jurnal Rekayasa Vol. 15 No. 2, Desenber 2017.

Hash, Phillip M. - Musik at the Illinois Asylum for Feeble-Minded Children: 1865-1920. Journal of Historical Research in Musik Education- vol. 32, (1), 2010, pp. 37-56.

Hogan, D., Halpenny, A.M., \& Greene, S. (2002). Children's Experience of Parental Separation. Dublin : Trinity College.

Kamil, Mustofa. 2012. Model Pendidikan dan Pelatihan (Konsep dan Aplikasi). Bandung: Alfabeta

Megahati R, Maizeli A, Fitriani. (2019). Pemberdayaan Anak-Anak Panti Asuhan PGAI dan Darul Ma'rif di Kota Padang Menjadi Bioentrepreneur. Jurnal Penelitian dan Pengabdian Kepada Masyarakat UNSIQ (2019) 6(2) 50-53. doi: 10.32699/pP2M.v6i2.568.

Sandri, Ritna. (2015). Perilaku Bullyingpada Remaja Panti Asuhan Ditinjau dari Kelekatan dengan Teman Sebaya dan Harga Diri. Jurnal Psikologi Tabularasavolume 10, NO.1, APRIL 2015: 43 - 57.

Saputra, D. N. (2020). Effort to Improve Elementary Students Interest On Music Subject With "Learning By Doing" Method Class. ADI Journal on Recent Innovation (AJRI), 2(2), 106-112. https://doi.org/10.34306/ajri.v2i2.74

Sulthoni, Yahya. (2013). Strategi Pembentukan Karakter Anakdi Panti Asuhan Muhammadiyah Wiyung Surabaya. Jurnal Kajian Moral dan Kewarganegaraan Nomor 1 Volume 1 Tahun 2013.

Suyanto, Bagong. (2003). Pelanggaran Hak dan Perlindungan Sosial Bagi Anak Rawan. Surabaya: Airlangga University Press

Suyanto, Bagong. (2010). Masalah Sosial Anak. Jakarta: Prenada Media Group

Supriadi. (2019). Pendampingan Keagamaan Bagi Anak-Anak Keluarga Broken Home Di Pondok Pesantren Dan Panti Asuhan Sabilul Huda Yogyakarta. At-Thullab jurnal Mahasiswa Studi Islam (2019) 1(2) 118-133. ISSN: 2685-8924. 
Usman, Hardius \& Nahrowi, Djalal. (2004). Pekerja Anak di Indonesia. Jakarta: PT Gramedia Widiasarana Indonesia.

Yusuf, Syamsu. 2007. Psikologi Perkembangan Anak dan Remaja. Bandung: PT. Remaja Rosda. 